2008

\title{
Otolith Chemistry Indicates Population Structuring By The Antarctic Circumpolar Current
}

Julian R. Ashford

Old Dominion University

Cynthia M. Jones

Old Dominion University, cjones@odu.edu

Eileen E. Hofmann

Old Dominion University, ehofmann@odu.edu

Inigo Everson

Carlos A. Moreno

See next page for additional authors

Follow this and additional works at: https://digitalcommons.odu.edu/ccpo_pubs

Part of the Aquaculture and Fisheries Commons, Marine Biology Commons, and the Oceanography Commons

\section{Repository Citation}

Ashford, Julian R.; Jones, Cynthia M.; Hofmann, Eileen E.; Everson, Inigo; Moreno, Carlos A.; Duhamel, Guy; and Williams, Richard, "Otolith Chemistry Indicates Population Structuring By The Antarctic Circumpolar Current" (2008). CCPO Publications. 81.

https://digitalcommons.odu.edu/ccpo_pubs/81

\section{Original Publication Citation}

Ashford, J.R., Jones, C.M., Hofmann, E.E., Everson, I., Moreno, C.A., Duhamel, G., \& Williams, R. (2008). Otolith chemistry indicates population structuring by the Antarctic Circumpolar Current. Canadian Journal of Fisheries and Aquatic Sciences, 65(2), 135-146. doi: $10.1139 /$ fo7-158 
Authors

Julian R. Ashford, Cynthia M. Jones, Eileen E. Hofmann, Inigo Everson, Carlos A. Moreno, Guy Duhamel, and Richard Williams 


\title{
Otolith chemistry indicates population structuring by the Antarctic Circumpolar Current
}

\author{
Julian R. Ashford, Cynthia M. Jones, Eileen E. Hofmann, Inigo Everson, \\ Carlos A. Moreno, Guy Duhamel, and Richard Williams
}

\begin{abstract}
Large-scale transport of seawater in ocean currents may generate spatially complex population structure through the advection of life stages of marine fish species. To test this, we compared the chemistry of otolith nuclei from Patagonian toothfish (Dissostichus eleginoides), presently managed as spatially discrete populations corresponding to fishing management areas along the Antarctic Circumpolar Current (ACC), which transports water eastward around the Southern Ocean. The chemistry of otolith nuclei, laid down during early life, differed significantly between fishing areas off South America and the Antarctic and between some Antarctic areas. However, we found significant discrepancies from expectation for a population structure corresponding to fishing areas. We also found evidence of four groups of fish with different early life chemistry: one associated with South America and three Antarctic groups showing mixing consistent with advective transport along the ACC. These results suggest that toothfish populations are structured by their physical environment; population abundance and persistence may rely on a restricted number of breeding members with access to spawning grounds, whereas fisheries may rely substantially on nonbreeding vagrants transported from fishing areas upstream.
\end{abstract}

Résumé : Le transport à grande échelle de l'eau de mer par les courants océaniques peut produire des structures de population complexes par advection des différents stades vitaux des espèces de poissons marins. Pour tester cet énoncé, nous avons comparé la chimie des noyaux des otolithes chez la légine australe (Dissostichus eleginoides), une espèce qui est actuellement gérée comme étant formée de populations discontinues dans l'espace et correspondant aux unités de gestion de la pêche le long du courant circumpolaire antarctique (ACC) qui transporte l'eau vers l'est dans l'Océan austral. La chimie des noyaux des otolithes, déterminée tôt dans le cycle biologique, differe significativement dans les zones de pêche au large de l'Amérique du Sud et dans celles de l'Antarctique, ainsi que dans certaines zones de l'Antarctique. Nous trouvons cependant d'importantes discordances par rapport à la structure de population à laquelle on pourrait s'attendre si celle-ci était reliée aux zones de pêche; il y a des indications de l'existence de quatre groupes de poissons avec une chimie différente au cours des premiers stades, un associé à l'Amérique du Sud et trois groupes antarctiques qui présentent des mélanges compatibles avec le transport advectif le long de ACC. Ces résultats indiquent que les populations de légines sont structurées par leur environnement physique; l'abondance et la persistance des populations doit peut-être alors dépendre d'un petit nombre de reproducteurs qui ont accès aux lieux de reproduction, alors que la pêche dépend de manière importante de poissons errants non reproducteurs qui sont transportés dans le courant à partir des zones de pêche.

[Traduit par la Rédaction]

\section{Introduction}

Population structure and advection

Managers of oceanic fisheries frequently rely on stock assessment models that assume a randomly mixing, closed population delineated by barriers that curtail exchange with neighbouring populations. Physical barriers cited include deep water and oceanic fronts (e.g., Kingsford 1993; Loeb et al. 1993). Yet fronts are often associated with fast-moving currents capable of transporting fish between habitats and across deep water. Where these currents result in movement to incompatible habitat, life stages are lost to the source population through advective mortality. Where currents connect to appropriate habitat, advection can structure marine popu-

Received 17 January 2007. Accepted 23 July 2007. Published on the NRC Research Press Web site at cjfas.nrc.ca on 9 January

2008.

J19771

J.R. Ashford ${ }^{1}$ and C.M. Jones. Center for Quantitative Fisheries Ecology, Old Dominion University, Norfolk, VA 23529 , USA.

E.E. Hofmann. Center for Coastal Physical Oceanography, Old Dominion University, Norfolk, VA 23529, USA.

I. Everson. Environmental Sciences Research Centre, School of Applied Sciences, Anglia Polytechnic University, East Road, Cambridge CB1 1PT, United Kingdom.

C.A. Moreno. Instituto de Ecología y Evolución, Universidad Austral de Chile, Casilla 567, Valdivia, Chile.

G. Duhamel. Museum National d'Histoire Naturelle, 43 Rue Cuvier, 75231 Paris CEDEX 05, France.

R. Williams. Australian Antarctic Division, Channel Highway, Kingston, Tasmania 7050, Australia.

${ }^{1}$ Corresponding author (e-mail: jashford@odu.edu). 
lations in spatially complex ways (e.g., Harden Jones 1968; Cushing 1981), promoting overlapping distributions of older stages that were nevertheless spawned on separate grounds.

Advection can connect these different populations genetically if transported fish remain to breed in their new area rather than returning to where they were spawned. This connectivity can be important to the persistence of populations; migration from source populations, where high recruitment relative to mortality allows emigration, can maintain sink populations, where low recruitment relative to mortality may otherwise lead to extinction (Pulliam 1988; Polachek 1990). If harvest interrupts the supply of migrants by source populations, it will reduce abundance over an extended area.

Even when advected fish do not breed or return to their original population, they can remain as nonbreeding vagrants (Sinclair 1988; Sinclair and Iles 1989). Population persistence may then depend on only those fish that have access to their spawning grounds, whose fecundity and rate of survival is capable of offsetting the loss of vagrants through advection. If so, harvest of these breeding members can interrupt the supply of vagrants, like the harvest of source populations supplying migrants, with a disproportionate impact on abundance over a wide area.

To examine population structure, researchers have used approaches such as artificial tags, population vital rates, and genetics (e.g., Ihssen et al. 1981). Although these approaches are generally efficient at testing whether fish are from a single panmictic population or not, they are less effective in telling whether spatial heterogeneity is due to discrete, closed populations or spatially complex structure, where fish come from more than one population. Success in assigning individual fish to a population using hyper-variable genetic markers nevertheless requires that the underlying populations have been identified and the multilocus genotypes of a representative sample are known (e.g., Cornuet et al. 1999). A more recent approach in oceanic fisheries is the use of natural chemical markers in otoliths, which show characteristic properties related to the environment to which fish are exposed (e.g., Edmonds et al. 1991). Growth increments in otoliths, used for aging fish, provide a chronology covering the life history to capture. One consequence is that the chemistry of otolith nuclei, laid down during early life, can be used to detect early spatial separation resulting from segregation during spawning (e.g., Campana et al. 1994) and hence population structure.

\section{Physical structuring of populations in the Southern Ocean}

The Polar Front (PF), one of several within the Antarctic Circumpolar Current (ACC), separates regions around South America and the Antarctic into different hydrographic regimes, and frontal currents may disperse life stages into deep water away from suitable habitat (e.g., Rogers et al. 2006). Recently, genetic data indicated a sharp population boundary in the vicinity of the PF between Patagonian toothfish (Dissostichus eleginoides) along the Patagonian Shelf and around South Georgia in the Southwest Atlantic (Fig. 1) (Shaw et al. 2004), corroborating evidence from length-atage data (Ashford 2001).
Yet the ACC also connects the major southern hemisphere continents and islands and banks around the Antarctic and may promote ecologically important linkages (Hofmann and Murphy 2004). There is strong evidence that another front in the ACC, the Southern ACC Front, transports Antarctic krill (Euphausia superba) from the western Antarctic Peninsula and southern Scotia Sea to supply nonbreeding stocks off South Georgia on a time scale of 2-12 months (Hofmann et al. 1998; Murphy et al. 2004; Fach et al. 2006). Fronts in the ACC penetrate the entire water column (e.g., Nowlin and Clifford 1982) and are identifiable around the Antarctic (Hofmann 1985; Orsi et al. 1995) associated with biological production due to upwelling. Under these conditions, marine organisms dispersed by frontal currents may survive, like krill from the Antarctic Peninsula, to be advected to appropriate habitat downstream, structuring populations in spatially complex ways.

\section{Population connectivity and Patagonian toothfish}

In contrast with krill, the otoliths in marine fish provide a way to test directly for physical structuring of populations. Recently, chemistry in the otolith nuclei of toothfish have detected the population division between the Patagonian Shelf and South Georgia (Ashford et al. 2006; Ashford and Jones 2007). Toothfish are managed off South America within national Exclusive Economic Zones (EEZs) and in the Antarctic by the Commission of the Convention for the Conservation of Antarctic Marine Living Resources (CCAMLR) as spatially discrete stocks corresponding to fishing areas around islands and seamounts. This assumes no movement between fishing areas, yet available data indicate young stages of toothfish are pelagic (North 2002), and mature adults are inferred to be neutrally buoyant (Oyarzun 1988; Eastman 1993), considerably reducing the energetic cost of dispersal. They live up to $50+$ years (Ashford 2001; Horn 2002), substantially longer than krill, and have been recaptured far from where they were tagged (e.g., Williams et al. 2002) or spawned (Moller et al. 2003).

Moreover, age-at-length frequencies, while varying between the Falkland Islands and South Georgia, showed no differences between South Georgia and Kerguelen Island downstream (Ashford 2001). These data suggest that the ACC provides opportunities to move along the current with little energetic cost, but constrains movement in other directions (Ashford et al. 2003). Evidence from genetic studies is mixed: $(i)$ little heterogeneity between South Georgia and some habitats downstream, but differentiation with others (Rogers et al. 2006); (ii) little differentiation between Prince Edward Island in the Indian Ocean and Crozet and Kerguelen islands further downstream (Appleyard et al. 2004), but heterogeneity among Heard Island on the Kerguelen Plateau, Macquarie Island in the Pacific Ocean, and South Georgia (Appleyard et al. 2002).

These results may be explained by spatially complex population structure, with heterogeneity resulting from fish mixing in different frequencies from more than one population. Similarities, on the other hand, may result from low levels of gene flow between populations that homogenize differences, rendering genetic markers incapable of distinguishing population structure. Otolith chemistry, in contrast, takes advan- 
Fig. 1. Detailed maps of the (a) Atlantic, (b) Indian, and (c) Pacific sectors of the Southern Ocean, showing mean position of major fronts and sampling areas. SAF, Subantarctic Front; PF, Polar Front; SACCF, southern Antarctic Circumpolar Current Front, southern boundary of the ACC is shown as a broken line (Orsi et al. 1995). Arrows show current direction. Sampling areas: 1, Chile 1996; 2 , Falkland Islands 1997; 3, Kerguelen Island 1996; 4, Macquarie Island 1996; 5, South Georgia 1996; 6, South Georgia 1997; 7, South Georgia 1998.

(a)

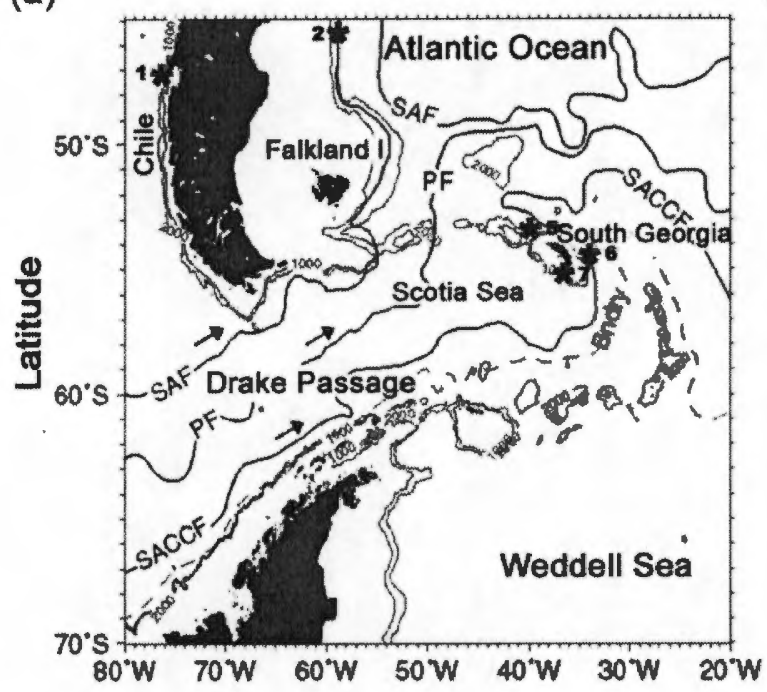

(b)

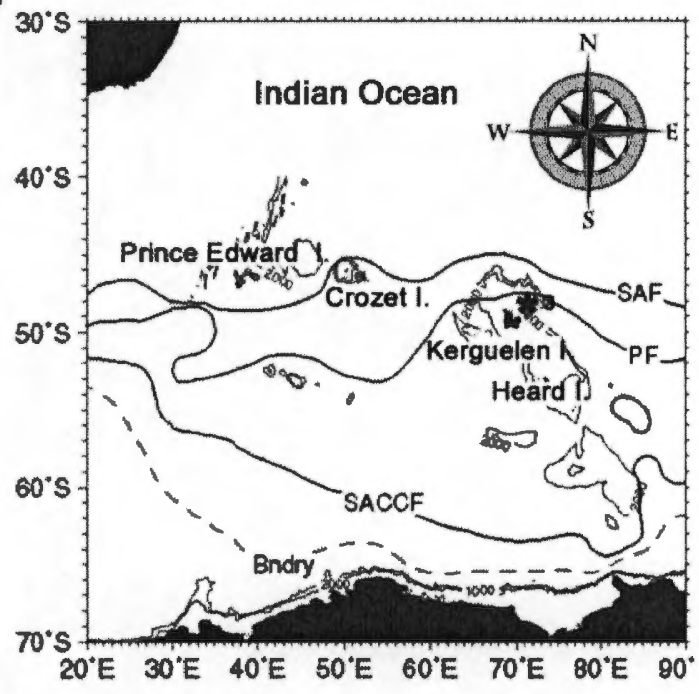

Longitude

(c)

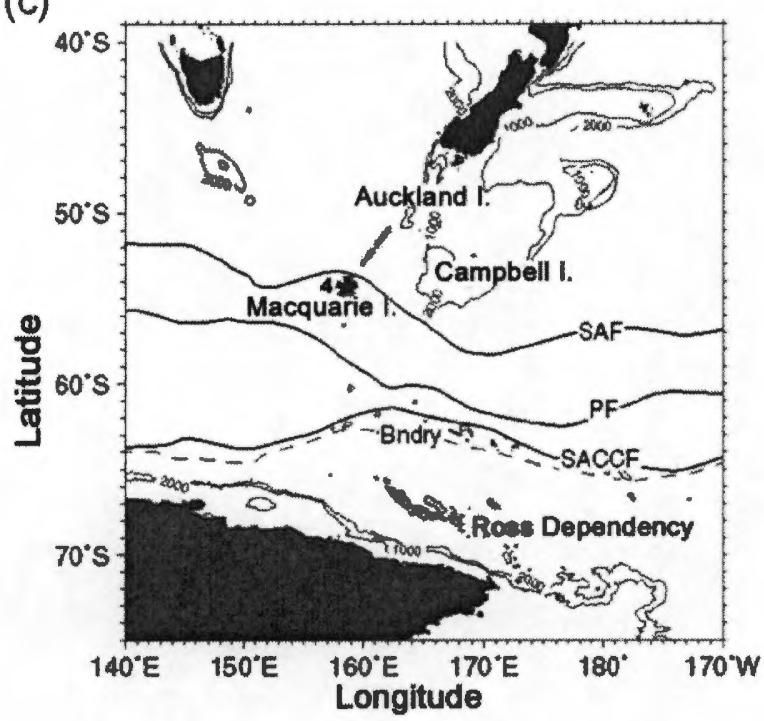

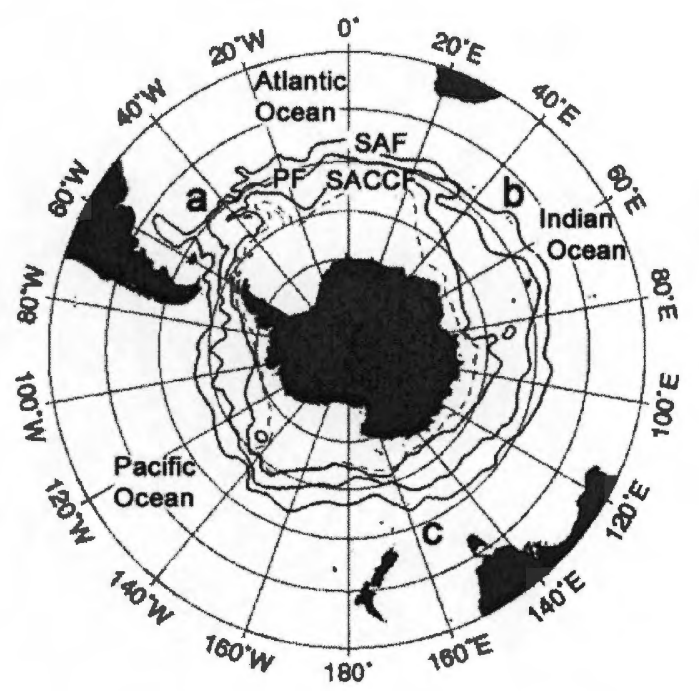

detected by genetic approaches (Ashford et al. 2006). In this study, therefore, we used nucleus chemistry to test whether toothfish are distributed in spatially discrete, closed populations that correspond to fishing areas or in a more complex structure resulting from advection along the ACC, in which sampling areas show mixing with fish carrying similar early life chemistry to those upstream. Sampling around the Southern Ocean and along the eastern boundary of the southern Pacific Ocean and western boundary of the southern Atlantic Ocean, we undertook the first integrated study

Otolith nuclei have already suggested population heterogeneity in toothfish off the Patagonian Shelf, which was not 
linking nucleus chemistry with the physical structuring of populations across the range of an oceanic species.

\section{Materials and methods}

\section{Otolith analysis procedures}

Otoliths were collected between March and April 1996 from commercial catches of Patagonian toothfish off the northern continental slope of South Georgia (United Nations Food and Agriculture Organization Statistical Sub-Area 48.3); off the eastern continental slope of Kerguelen (Division 58.5.1); and off the west coast of the Macquarie Island EEZ (Fig. 1). Details of otolith collection are found in Ashford et al. (2005), and a brief summary is given here. For the region around South America, observers sampled fish from artesanal fishermen returning to Chiloe Island in the Chilean national EEZ. Between April and May 1997, observers collected a second set of samples off the slope of the Patagonian Shelf northeast of the Falkland Islands Conservation Zone (FCZ) and off the eastern slope of South Georgia. At each collection, observers sampled female toothfish between 90 and $110 \mathrm{~cm}$ to minimize effects due to sex and life stage. Off Chile, otoliths could not be collected before removal of gonads by fishermen, and sex data were not recorded. We also selected otoliths randomly from observer sample sets taken in 1998 off the southern shelf slope of South Georgia. All samples were taken from depths greater than $1000 \mathrm{~m}$, except at Macquarie Island, where the depths were $\sim 400-500 \mathrm{~m}$.

Otoliths were dried and stored in envelopes and returned to the laboratory at Old Dominion University, Norfolk, Virginia, USA. Preparation of otoliths for elemental analysis is outlined in Ashford et al. (2005). We used a Finnegan Mat Element 2 double-focusing sector-field inductively coupled plasma mass spectrometer (ICP-MS) located at the Laboratory for Isotope and Trace Element Research (LITER) at Old Dominion University to examine otoliths for minor and trace element chemistry. Instrument details are given in Jones and Chen (2003). Samples were introduced in automated sequence (Chen et al. 2000) using a New Wave Research EO LUV 266 laser ablation system and a PFA microflow nebulizer. Ablated otolith material from the sample cell was mixed in the spray chamber with aerosol of $1 \% \mathrm{HNO}_{3}$ introduced by the nebulizer, and the mixture was then carried to the ICP torch. Laboratory calibration standards consisted of known-concentration, multi-element solutions synthesized from stock single element standards and were similarly introduced to the spray chamber by the nebulizer as an aerosol before being carried to the ICP torch. Blanks of $1 \% \mathrm{HNO}_{3}$ aerosol also were introduced to the chamber by the nebulizer.

For quality control, we used dissolved otolith reference material obtained from the National Research Council of Canada. To control for operational variability in the laserICP-MS, a randomized blocks design was used with each petrographic slide as the blocking factor, considered randomly drawn, with each sampling area considered a fixed treatment. Blank and standard readings of count rate (counts $\cdot \mathrm{s}^{-1}$ ) were obtained before and after random presentation of the otolith sections in each block. Readings of reference material were obtained before sample presentation.
Otoliths were analysed for ${ }^{48} \mathrm{Ca},{ }^{25} \mathrm{Mg},{ }^{55} \mathrm{Mn},{ }^{88} \mathrm{Sr}$, and ${ }^{138} \mathrm{Ba}$ and reported as ratios to ${ }^{48} \mathrm{Ca}$. To calculate element: $\mathrm{Ca}$ (Me. $\mathrm{Ca}^{-1}$ ) ratios, background counts were subtracted from otolith counts by interpolating between readings taken before and after each block of otoliths, and the corrected otolith counts were converted to $\mathrm{Me} \cdot \mathrm{Ca}^{-1}$ concentrations using the standards. To sample the nucleus, we used a grid raster type $200 \mu \mathrm{m} \times 200 \mu \mathrm{m}$ with a laser beam of diameter $20 \mu \mathrm{m}$ traveling at $6 \mu \mathrm{m} \cdot \mathrm{s}^{-1}$, set at $60 \%$ power and frequency at $10 \mathrm{~Hz}$, giving a predicted crater depth of approximately $100 \mu \mathrm{m}$ (Jones and Chen 2003, eq. 3). Dwell time was $15.0 \mathrm{~ms}$.

\section{Statistical methods}

A spatially discrete population structure that corresponds to fishing areas implies fish in each area were spawned separately from those in other areas and therefore were exposed to different early life environments. This in turn would be recorded in their otolith chemistry. To test for these differences, we applied analysis of variance (ANOVA), using separate univariate analyses to examine the behaviour of each element ratio. Multivariate outliers were identified by plotting robust squared Mahalanobis distances of the residuals $\left(D_{i}^{2}\right)$ against the corresponding quantiles (Q-Q plot) of the $\chi^{2}$ distribution.

The assumption of multivariate normality was checked analytically using tests $(\alpha=0.05)$ based on Mardia's multivariate skewness and kurtosis measures (Khattree and Naik 1999) and graphically using Q-Q plots of squared Mahalanobis distances $\left(d_{i}^{2}\right)$. Data distributions were not normal, showing long tails instead. We used variance-stabilizing transformations from the ladder of powers (Kuehl 1994; Ashford et al. 2007), which also fulfilled the assumption of multivariate normality. The data transformations selected were $y^{-0.2}$ for $\mathrm{Mg} \cdot \mathrm{Ca}^{-1}, y^{0.25}$ for $\mathrm{Mn} \cdot \mathrm{Ca}^{-1}, y^{0.8}$ for $\mathrm{Sr} \cdot \mathrm{Ca}^{-1}$, and $y^{-0.5}$ for $\mathrm{Ba} \cdot \mathrm{Ca}^{-1}$, which reduced the tails of the distributions in a similar way to standard lognormal transformations.

Because variance-covariance matrices were not equal according to Bartlett's modification $\left(\chi^{2}=96.7, \mathrm{df}=60, p>\right.$ $\left.\chi^{2}=0.0019\right)$, multivariate ANOVA was inappropriate, and we used univariate ANOVA for each $\mathrm{Me} \cdot \mathrm{Ca}^{-1}$ ratio instead. Residuals for each treatment were normally distributed (Kolmogorov-Smirnov test; $\alpha=0.05$ ), except for fish taken off Chile for $\mathrm{Mg} \cdot \mathrm{Ca}^{-1}$ only (Kolmogorov-Smirnov test; $p=$ $0.034)$. All $\mathrm{Me} \cdot \mathrm{Ca}^{-1}$ ratios showed equality of variances $\left(F_{\max }\right.$ test; $t=7, v=17 ; \alpha=0.01$ ). As a result, we used ANOVA to test between sampling areas separately for each trace element measured, with Student-Newman-Keuls (SNK) multiple range tests for pairwise comparisons between sampling areas, adjusted for an experiment-wise $\alpha=$ 0.0125 . We calculated power $1-\beta$ in an a posteriori manner separately for each ANOVA test (Sokal and Rohlf 1995) and found $1-\beta>0.99$ for all four elements.

Spatial heterogeneity can also result when fish, though spawned separately, then disperse and mix in different proportions between sampling areas. Therefore, to examine whether spatial heterogeneity was due to discrete populations or mixing of more than one, we examined the data from individual fish graphically using nonmetric multidimensional scaling (NMDS) (Kruskal and Wish 1978; Schiffman et al. 1981). Because the variables had different absolute magnitudes and 
Fig. 2. Elemental ratio ( $\left.\mathrm{Me} \cdot \mathrm{Ca}^{-1}\right)$ concentrations found in the nuclei of otoliths from Patagonian toothfish (Dissostichus eleginoides) captured at sampling areas in the Southern Ocean between 1996 and 1997. Bars show standard error. C, Chile; FI, Falkland Islands; SG-N, north South Georgia; SG-E, east South Georgia; K, Kerguelen Island; M, Macquarie Island; SG-S, south South Georgia.
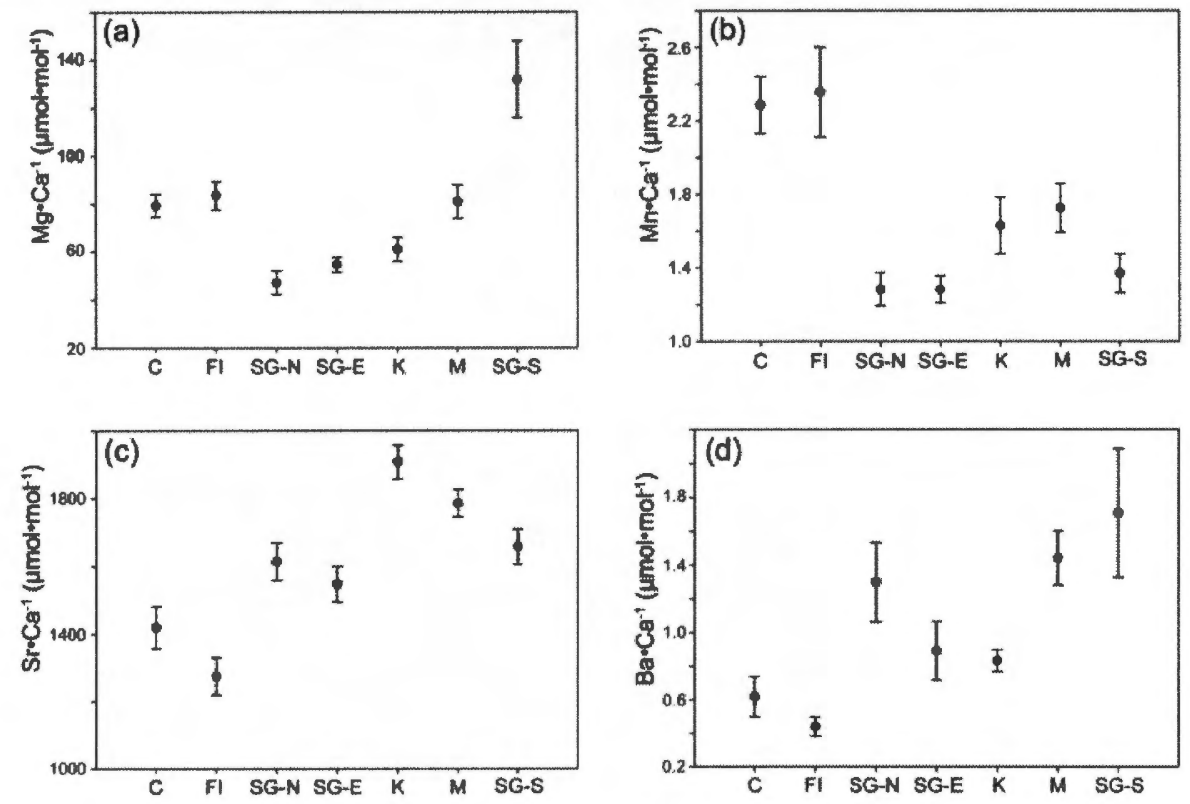

\section{Sampling area}

ranges, they were standardized to the same scale. Constructing a dissimilarity matrix based on Euclidean distances, we created a two-dimensional projection of distance between individual fish using a convergence criterion of Stress $<0.01$. We also employed cluster analysis to detect fish crossing between sampling areas using Ward's minimum variance hierarchical approach on the standardized data. To determine the quality of clustering, we used root mean square standard deviation, semipartial $R^{2}, R^{2}$, and between-cluster sum of squares to measure the loss of homogeneity through successive merging of clusters. The appropriate number of clusters was taken as that below which the measures began to change markedly (Khattree and Naik 2000).

\section{Results}

Otolith nucleus chemistry showed significant heterogeneity between samples from South American and Antarctic fishing areas (Fig. 2, Tables 1-4). Samples taken from the Chilean EEZ and north of the FCZ showed similar concentrations of all four element ratios, but both showed concentrations of $\mathrm{Mg} \cdot \mathrm{Ca}^{-1}$ $\left(\bar{y}_{\mathrm{C}}=79.3 \mu \mathrm{mol} \cdot \mathrm{mol}^{-1} ; \bar{y}_{\mathrm{FI}}=83.6 \mu \mathrm{mol} \cdot \mathrm{mol}^{-1}\right)$ that were significantly higher than samples taken from north and east of South Georgia $\left(\bar{y}_{\mathrm{SGn}}=47.2 \mu \mathrm{mol} \cdot \mathrm{mol}^{-1} ; \bar{y}_{\mathrm{SGe}}=54.6 \mu \mathrm{mol} \cdot \mathrm{mol}^{-1}\right)$ and significantly lower than the sample taken from south of South Georgia $\left(\bar{y}_{\mathrm{SGs}}=131.9 \mu \mathrm{mol} \cdot \mathrm{mol}^{-1}\right)$. Mean concentrations of $\mathrm{Mn} \cdot \mathrm{Ca}^{-1}$ off Chile $\left(\bar{y}_{\mathrm{C}}=2.29 \mu \mathrm{mol} \cdot \mathrm{mol}^{-1}\right)$ and the $\mathrm{FCZ}\left(\bar{y}_{\mathrm{FI}}=\right.$ $2.36 \mu \mathrm{mol} \cdot \mathrm{mol}^{-1}$ ) were higher than all Antarctic areas, significantly so for Kerguelen and all South Georgia samples (ranging from $\bar{y}_{\mathrm{SGe}}=1.28 \mu \mathrm{mol} \cdot \mathrm{mol}^{-1}$ to $\bar{y}_{\mathrm{K}}=1.63 \mu \mathrm{mol} \cdot \mathrm{mol}^{-1}$ ). On the other hand, mean concentrations of Sr$\cdot \mathrm{Ca}^{-1}$ off Chile $\left(\bar{y}_{\mathrm{C}}=\right.$ $\left.1419.8 \mu \mathrm{mol} \cdot \mathrm{mol}^{-1}\right)$ and the FCZ $\left(\bar{y}_{\mathrm{Fl}}=1274.7 \mu \mathrm{mol} \cdot \mathrm{mol}^{-1}\right)$ were lower than those in all Antarctic areas, significantly so for
Kerguelen, Macquarie, and south of South Georgia (ranging from $\bar{y}_{\text {SGs }}=1657.1 \mu \mathrm{mol} \cdot \mathrm{mol}^{-1}$ to $\bar{y}_{\mathrm{K}}=1907.6 \mu \mathrm{mol} \cdot \mathrm{mol}^{-1}$ ). Mean concentrations of $\mathrm{Ba} \cdot \mathrm{Ca}^{-1}$ off Chile $\left(\bar{y}_{\mathrm{C}}=\right.$ $\left.0.62 \mu \mathrm{mol} \cdot \mathrm{mol}^{-1}\right)$ and the $\mathrm{FCZ}\left(\bar{y}_{\mathrm{FI}}=0.44 \mu \mathrm{mol} \cdot \mathrm{mol}^{-1}\right)$ were also significantly lower than those in all Antarctic areas (ranging from $\bar{y}_{\mathrm{K}}=0.83 \mu \mathrm{mol} \cdot \mathrm{mol}^{-1}$ to $\bar{y}_{\mathrm{SGs}}=1.71 \mu \mathrm{mol} \cdot \mathrm{mol}^{-1}$ ).

Consistent with spatially discrete populations corresponding to fishing areas, the otolith nuclei showed further heterogeneity between samples from fishing areas within

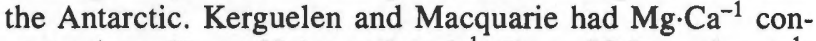
centrations $\left(\bar{y}_{K}=60.1 \mu \mathrm{mol} \cdot \mathrm{mol}^{-1} ; \bar{y}_{M}=80.9 \mu \mathrm{mol} \cdot \mathrm{mol}^{-1}\right)$ that were significantly higher than samples from north and east of South Georgia and significantly lower than those south of South Georgia. Kerguelen also showed significantly higher concentrations of $\mathrm{Sr} \cdot \mathrm{Ca}^{-1}$ than all South Georgia samples (ranging from $\bar{y}_{\mathrm{SGe}}=1547.5 \mu \mathrm{mol} \cdot \mathrm{mol}^{-1}$ to $\left.\bar{y}_{\mathrm{SGs}}=1657.1 \mu \mathrm{mol} \cdot \mathrm{mol}^{-1}\right) ;$ Macquarie showed mean concentrations of $\mathrm{Sr} \cdot \mathrm{Ca}^{-1}\left(\bar{y}_{\mathrm{M}}=1785.9 \mu \mathrm{mol} \cdot \mathrm{mol}^{-1}\right)$ that were higher than all South Georgia samples, significantly so compared with east of South Georgia.

However, mean $\mathrm{Me} \cdot \mathrm{Ca}^{-1}$ concentrations showed major discrepancies from expectation for a population structure corresponding to fishing areas. Despite coming from the respective eastern and western boundaries of separate ocean systems around South America, mean concentrations of samples taken from fishing areas off Chile and the FCZ showed no significant difference (Fig. 2, Tables 1-4). Similarly in the Antarctic, ANOVA detected no heterogeneity between samples taken from fishing areas around Kerguelen and Macquarie. In contrast, within a single fishing area off South Georgia, samples were significantly different; the sample taken south of the island had significantly higher $\mathrm{Mg} \cdot \mathrm{Ca}^{-1}$ concentrations than those taken to the north and east. 
Table 1. Results from analysis of variance (ANOVA) and Student-Newman-Keuls tests of $\mathrm{Mg} \cdot \mathrm{Ca}^{-1}$, showing differences in concentrations measured in the otolith nuclei of Patagonian toothfish (Dissostichus eleginoides) between sampling areas off South America and in the Antarctic.

\begin{tabular}{lrllll}
\hline & df & SS & MS & $F$ & $p$ \\
\hline Sample & 6 & 0.0765 & 0.0127 & 16.38 & $<0.0001$ \\
Error & 123 & 0.0957 & 0.0008 & & \\
Total & 129 & 0.1722 & & & \\
\hline
\end{tabular}

\begin{tabular}{lllllll} 
& & & & & & \\
\cline { 5 - 7 } SG-S & FI & C & M & K & SG-E & SG-N \\
\hline Area & C & FI & SG-N & SG-E & SG-S & K \\
\hline FI & NS & & & & & \\
SG-N & + & + & & & & \\
SG-E & + & + & NS & & & \\
SG-S & + & + & + & + & & \\
K & NS & NS & NS & NS & + & NS \\
M & NS & NS & + & + & + & + \\
\hline
\end{tabular}

Note: Lines denote no significant difference; NS, no significant difference; $t$, significant difference $(\alpha=0.05)$; C, southern Chile $(n=19)$; FI, Falkland Islands $(n=19)$; SG-N, north of South Georgia $(n=17)$; SG-E, east of South Georgia $(n=17) ; \mathrm{K}$, Kerguelen Island $(n=20)$; M, Macquarie Island $(n=20)$; SG-S, south of South Georgia $(n=17)$.

Table 2. Results from analysis of variance (ANOVA) and Student-Newman-Keuls tests of $\mathrm{Mn} \cdot \mathrm{Ca}^{-1}$, showing differences in concentrations measured in the otolith nuclei of Patagonian toothfish (Dissostichus eleginoides) between sampling areas off South America and in the Antarctic.

\begin{tabular}{|c|c|c|c|c|c|c|}
\hline & df & SS & MS & $F$ & $p$ & \\
\hline Sample & 6 & 0.5614 & 0.0936 & 9.57 & $<0.0001$ & \\
\hline Error & 123 & 1.2020 & 0.0098 & & & \\
\hline Total & 129 & 1.7634 & & & & \\
\hline SG-N & SG-E & SG-S & $\mathrm{K}$ & M & FI & $\mathrm{C}$ \\
\hline Area & C & FI & SG-N & SG-E & SG-S & $\mathrm{K}$ \\
\hline FI & NS & & & & & \\
\hline SG-N & + & + & & & & \\
\hline SG-E & + & + & NS & & & \\
\hline SG-S & + & + & NS & NS & & \\
\hline $\mathrm{K}$ & + & + & NS & NS & NS & \\
\hline M & NS & NS & NS & NS & NS & NS \\
\hline
\end{tabular}

Note: Refer to Table 1 for explanation of lines and definitions.

Examining the distribution of data graphically, multidimensional scaling corroborated the strong separation between the FCZ and both western and eastern South Georgia sampling areas (Stress $=0.14$; Fig. $3 a$ ). All three areas showed strong separation from southern South Georgia, which, although it included some fish similar to those taken north and east of the island, showed most fish to have a very different nucleus chemistry that implied a separate early life history. On the other hand, like the samples from western and eastern South Georgia, fish from west and east of South America showed similar nucleus chemistry distributions (Fig. 3b), indicating similar early life histories. Downstream of South Georgia along the ACC, samples from Kerguelen included fish similar to those taken north and east of South Georgia, but also included others with very different nucleus chemistry (Fig. 3c). Moreover, the nucleus chemistry distribution of these Kerguelen-caught fish was similar to that of those caught at Macquarie Island, and both showed similarities to fish taken from south of South Georgia.

Examining this further, cluster analysis indicated that the distributions detected using NMDS resolved most appropriately into four clusters (Table 5, Figs. $4 a, 4 b$ ); the statistical measures changed sharply when reducing to three clusters. Lower concentrations of $\mathrm{Sr} \cdot \mathrm{Ca}^{-1}$ and $\mathrm{Ba} \cdot \mathrm{Ca}^{-1}$ and higher 
Table 3. Results from analysis of variance (ANOVA) and Student-Newman-Keuls tests of $\mathrm{Sr} \cdot \mathrm{Ca}^{-1}$, showing differences in concentrations measured in the otolith nuclei of Patagonian toothfish (Dissostichus eleginoides) between sampling areas off South America and in the Antarctic.

\begin{tabular}{lrlrll}
\hline & \multicolumn{1}{l}{ df } & \multicolumn{1}{l}{ SS } & \multicolumn{1}{c}{ MS } & \multicolumn{1}{l}{$F$} & \multicolumn{1}{l}{$l$} \\
\hline Sample & 6 & 184140 & 30690 & 17.41 & $<0.0001$ \\
Error & 123 & 216839 & 1763 & & \\
Total & 129 & 400979 & & & \\
\hline
\end{tabular}

\begin{tabular}{llllllll}
\hline & & & & & & & \\
\cline { 3 - 4 } FI & C & SG-E & SG-N & SG-S & M & K \\
\hline Area & C & FI & SG-N & SG-E & SG-S & K \\
\hline FI & NS & & & & & \\
SG-N & NS & + & & & & & \\
SG-E & NS & + & NS & & & \\
SG-S & + & + & NS & NS & & \\
K & + & + & + & + & + & NS \\
M & + & + & NS & + & NS & \\
\hline
\end{tabular}

Note: Refer to Table 1 for explanation of lines and definitions.

Table 4. Results from analysis of variance (ANOVA) and Student-Newman-Keuls tests of $\mathrm{Ba} \cdot \mathrm{Ca}^{-1}$, showing differences in concentrations measured in the otolith nuclei of Patagonian toothfish (Dissostichus eleginoides) between sampling areas off South America and in the Antarctic.

\begin{tabular}{|c|c|c|c|c|c|c|}
\hline & df & SS & MS & $F$ & $p$ & \\
\hline Sample & 6 & 8.871 & 1.479 & 15.8 & $<0.0001$ & \\
\hline Error & 123 & 11.512 & 0.094 & & & \\
\hline Total & 129 & 20.383 & & & & \\
\hline M & SG-S & SG-N & $\mathbf{K}$ & SG-E & C & FI \\
\hline Area & $\mathrm{C}$ & FI & SG-N & SG-E & SG-S & $\mathbf{K}$ \\
\hline FI & NS & & & & & \\
\hline SG-N & + & + & & & & \\
\hline SG-E & + & + & NS & & & \\
\hline SG-S & + & + & NS & NS & & \\
\hline $\mathrm{K}$ & + & + & NS & NS & NS & \\
\hline M & + & + & NS & NS & NS & NS \\
\hline
\end{tabular}

Note: Refer to Table 1 for explanation of lines and definitions.

concentrations of $\mathrm{Mn} \cdot \mathrm{Ca}^{-1}$ separated cluster 1 fish $(n=38)$ from cluster $2(n=52)$ and cluster $3(n=24)$ fish; whereas $\mathrm{Mn} \cdot \mathrm{Ca}^{-1}$ and $\mathrm{Sr} \cdot \mathrm{Ca}^{-1}$ separated cluster 2 fish from cluster 3 fish. $\mathrm{Mg} \cdot \mathrm{Ca}^{-1}$ and $\mathrm{Mn} \cdot \mathrm{Ca}^{-1}$ separated cluster 4 fish $(n=16)$ from the other clusters. Cluster 1 fish were mostly caught off South America (79\%). The other three clusters were associated mostly with fish taken at sampling sites in the Antarctic ( $90 \%$ of cluster 2 fish; $83 \%$ of cluster 3 fish; $100 \%$ of cluster 4 fish). As indicated by multidimensional scaling, the percentage of fish from each cluster changed between Antarctic sampling areas. Off the north and east of South Georgia, almost all fish from Antarctic-associated clusters were from cluster $2(93 \%)$, whereas downstream at Kerguelen, $58 \%$ were from cluster 2 and the rest from cluster 3 . Further downstream still, off Macquarie Island, cluster 2 made up only $26 \%$ of the sample, and clusters 3 and 4 made up $53 \%$ and $21 \%$, respectively, of the sample. Off the south of South Georgia, $73 \%$ of fish from Antarctic-associated clusters were from cluster 4 .

\section{Discussion}

Otolith chemistry and toothfish population structure

The chemistry of otolith nuclei strongly suggested that toothfish population structure is considerably more complex than a series of spatially discrete populations corresponding to fishing areas. Samples taken off South America were very different from those caught in the Antarctic, independently 
Fig. 3. Relationships between individual Patagonian toothfish (Dissostichus eleginoides) taken from sampling areas in the Southern Ocean, using nonmetric multidimensional scaling (NMDS) based on Euclidean distances. Stress $=0.14$.

(a) Falkland Islands $(\square)$; north South Georgia ( $\Delta)$; east South Georgia $(\Delta)$; south South Georgia $(+)$; $(b)$ Chile $(\diamond)$, using Falkland Islands and north South Georgia as references; $(c)$ Kerguelen $(O)$ and Macquarie $(x)$ islands, using north South Georgia as a reference.
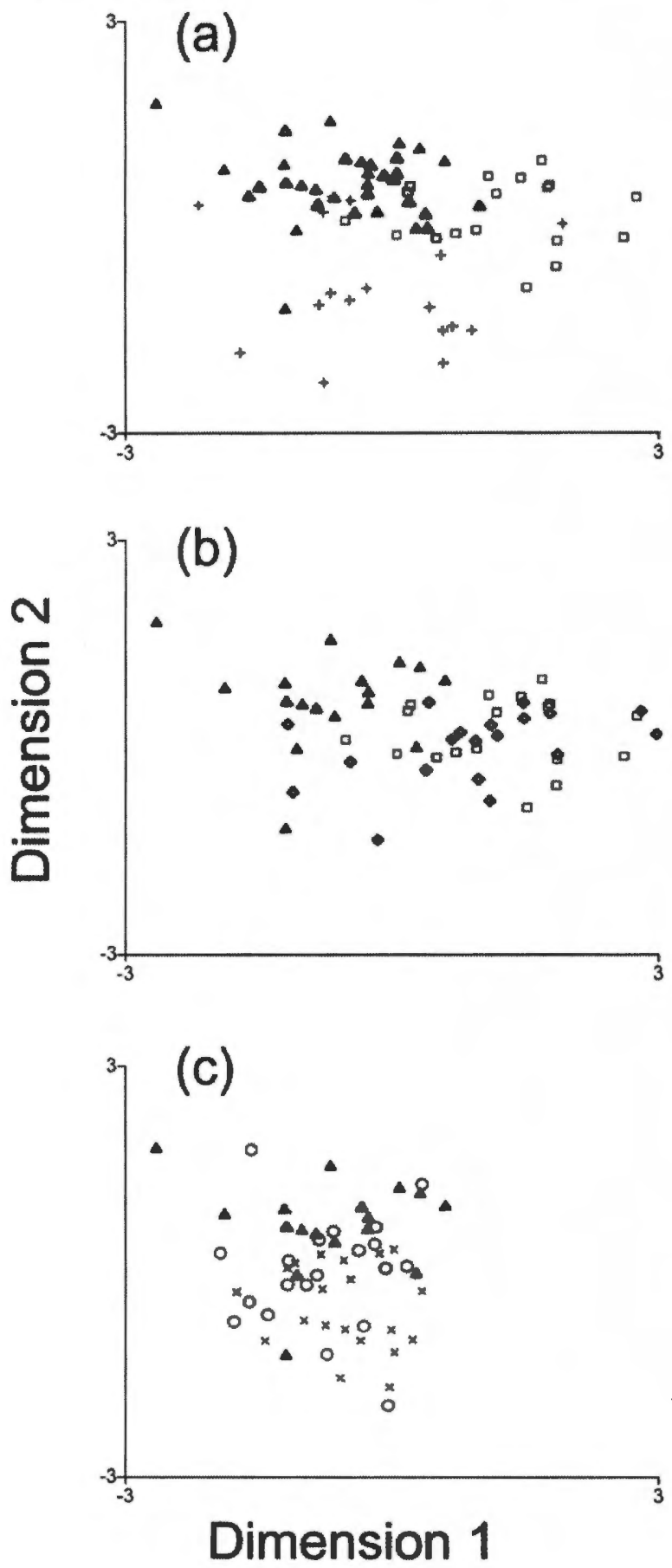

Table 5. Summary of statistics measuring quality of clustering.

\begin{tabular}{llllr}
\hline Cluster No. & RMSSTD & Semipartial $R^{2}$ & $R^{2}$ & BSS \\
\hline 6 & 0.645 & 0.028 & 0.656 & 14.6 \\
5 & 0.650 & 0.037 & 0.619 & 19.3 \\
4 & 0.731 & 0.057 & 0.562 & 29.3 \\
3 & 0.843 & 0.097 & 0.465 & 50.1 \\
2 & 0.857 & 0.136 & 0.329 & 70.2 \\
1 & 1.000 & 0.329 & 0.000 & 169.6 \\
\hline
\end{tabular}

Note: RMSSTD, root mean square standard deviation; BSS, between sum-of-squares. Gap in table shows marked change in measures, indicating an appropriate number of four clusters. Data is from cluster analysis using Ward's minimum variance approach for standardized trace element ratio concentrations measured in the nuclei of Patagonian toothfish (Dissostichus eleginoides) captured across the Southem Ocean.

Fig. 4. Allocation of Patagonian toothfish (Dissostichus eleginoides) captured at sampling areas in the Southern Ocean to four clusters $(\mathrm{Cl}-\mathrm{C} 4)$ based on early life history similarities recorded in the chemistry of otolith nuclei. Cluster analysis is based on Ward's minimum variance approach. (a) Composite bar chart showing all data; and individual bar charts for (b) Chile (C),

(c) Falkland Islands (FI); (d) north South Georgia (SG-N);

(e) east South Georgia (SG-E); (f) Kerguelen Island (K);

(g) Macquarie Island (M); (h) south South Georgia (SG-S).
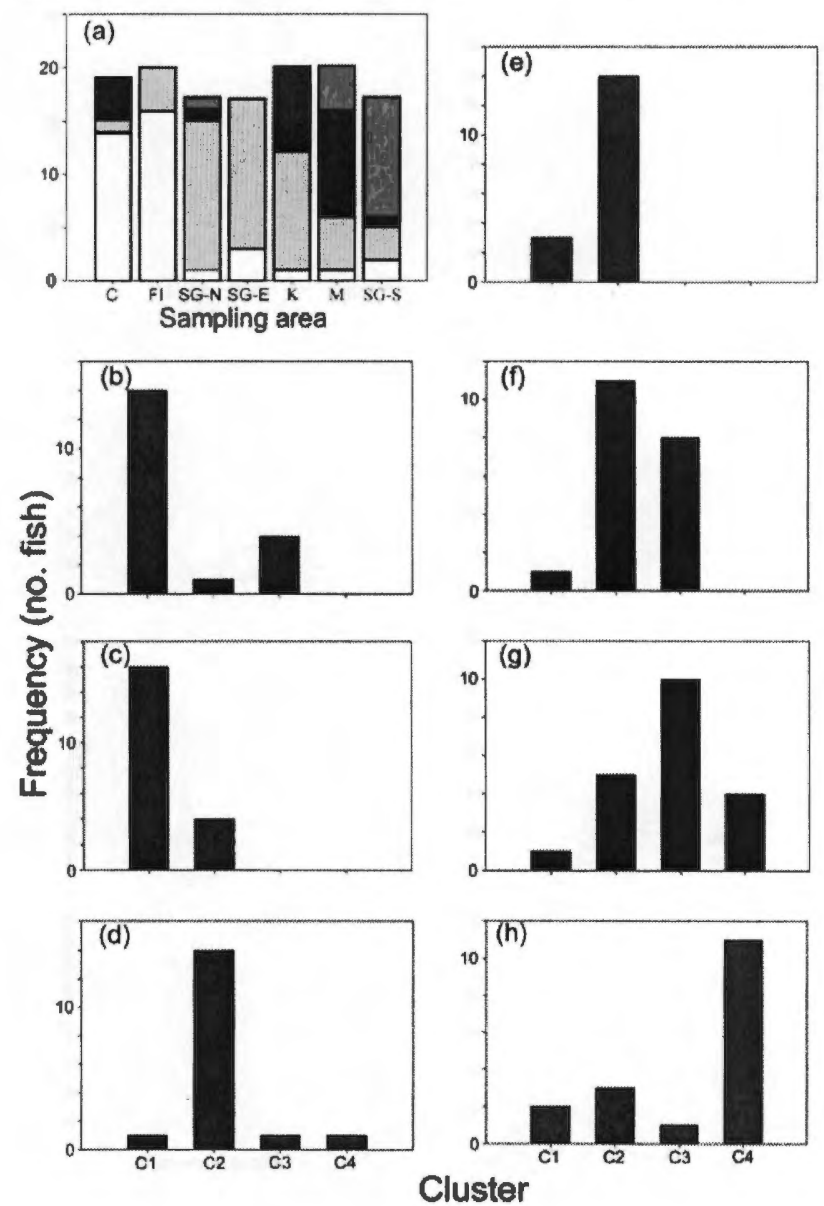
corroborating earlier results showing population isolation between fishing areas off the Patagonian Shelf and South Georgia (e.g., Shaw et al. 2004; Ashford et al. 2006; Rogers et al. 2006). However, in the first comparison between toothfish on either side of South America, we found no evidence of segregation during early life that would be consistent with spatially discrete populations; nucleus chemistry strongly suggested that toothfish had the same population structure. In contrast, at South Georgia, fish caught south of the island showed nucleus chemistry that was significantly different from those taken to the north and east, suggesting population heterogeneity within a single fishing area in the ACC.

The north and east South Georgia samples were also different from those taken downstream along the ACC, at Kerguelen and Macquarie islands, consistent with previous genetic data (Appleyard et al. 2002), although in contrast with the genetic data, ANOVA showed little heterogeneity between Kerguelen and Macquarie islands. Unlike genetic approaches, however, which rely on discriminating genetic frequencies between sampling areas, otolith chemistry data are highly amenable to techniques capable of detecting grouping within and across samples. These analyses suggested two groups of fish mixing at Kerguelen, one of which had similar early life distributions to north and east South Georgia and the other to Macquarie Island. The analyses also suggested that there was indeed heterogeneity between Kerguelen and Macquarie islands, but that this was due to the proportions of fish mixing from the same two groups, as well as fish from a third group that were present at Macquarie and not at Kerguelen. This third group showed considerable similarity to fish found off southern South Georgia.

\section{Otolith chemistry and hydrography}

Otolith chemistry has successfully discriminated spatial heterogeneity in several exclusively marine fish species (e.g., Edmonds et al. 1991; Campana et al. 1994). Validations for Patagonian toothfish demonstrated that the characteristic spatial properties of otolith markers resulted in correct allocation of fish to South American and Antarctic regions (Ashford et al. 2005; Ashford and Jones 2007). The chemistry of otolith edges, laid down immediately prior to capture, suggested that the distribution of otolith $\mathrm{Sr} \cdot \mathrm{Ca}^{-1}$ is related to temperature (Ashford et al. 2005), which in turn distinguishes Circumpolar Deep Water, the largest water mass by volume transported by the ACC (Sievers and Nowlin 1984), from Antarctic Intermediate Water, formed to the north of the PF primarily in the southwest Atlantic (Molinelli 1981; Sievers and Nowlin 1984). Concentrations of $\mathrm{Ba} \cdot \mathrm{Ca}^{-1}$ were associated with new production in the open ocean fueled by nitrate (Dehairs et al. 1992), as opposed to recycled nitrogen off continental shelves such as around South America. On the other hand, authigenic activity, particularly along the Patagonian Shelf, and resuspension from anoxic sediments (e.g., Bucciarelli et al. 2001) may explain enrichment of otolith $\mathrm{Mn} \cdot \mathrm{Ca}^{-1}$, whereas physiology most likely accounts for otolith $\mathrm{Mg} \cdot \mathrm{Ca}^{-1}$ distributions (Ashford et al. 2005, 2006).

Comparing fish from the Patagonian Shelf and the ACC in the Antarctic takes full advantage of the spatial properties of each of these markers. In the nucleus chemistry, all four showed strong contrasts between fish caught off South America and in the Antarctic, on either side of a recognized population boundary, which corroborated earlier results (Ashford et al. 2006). Earlier results also showed that environmental conditions diverged on either side of South America sufficiently to allocate fish with $79 \%-84 \%$ success using chemistry from their otolith edges (Ashford et al. 2005); even so, we found no evidence of early life segregation.

Despite lying downstream of one another, and therefore receiving similar water after a time lag for transport, fish from South Georgia and Kerguelen and Macquarie islands were correctly classified to sampling area at rates of between $50 \%$ and $67 \%$, compared with an expected $14 \%$ by chance alone. Strong contrasts from our results in the nucleus chemistry around South Georgia and between fish off north and east South Georgia and particularly Macquarie imply that spatial heterogeneity may be more strongly defined during early life because of the restricted area of spawning aggregations and the constrained spatial scales at which young stages can move actively. The quality of clustering changed sharply when reducing from four to three clusters, consistent with strong spatial contrasts experienced by the four groups of fish. Indeed, there was some evidence that the South American-associated cluster contained a further division, supported by prior evidence of two mixing South American populations (Ashford et al. 2006). However, the two groups would have accounted for considerably less variation than the Antarctic-associated clusters.

This heterogeneity is driven by physical and biogeochemical processes that continue within seawater during transport. Water continues to mix, substantially changing the biogeochemical properties of water around the ACC (Kroopnick 1985; Meredith et al. 1999a, 1999b). The physical structure of the ACC exerts a dominant control on biogeochemical distributions in the Southern Ocean (Pollard et al. 2002). As a consequence, the chemistry recorded in an otolith reflects association with different water masses, zones, and fronts along the ACC, often at quite fine scales. Water, not food, contributes the majority of strontium and barium deposited in the otoliths of marine fish (Walther and Thorrold 2006), and recent evidence shows that edge chemistry distinguished areas downstream of each other along the Patagonian Shelf, separating with $68 \%-81 \%$ success at spatial scales down to $200 \mathrm{~nm}$ (Ashford et al. 2007).

\section{Are populations structured by the ACC?}

Such lines of evidence strongly suggest that physical and biogeochemical heterogeneity generate strong early life contrasts not only across frontal systems but also between sampling areas connected by hydrographic transport. Most tellingly, otolith chemistry corroborated heterogeneity where it was previously found by genetic approaches (Smith and McVeagh 2000; Appleyard et al. 2002; Shaw et al. 2004). But it went further, allowing us to directly examine data for evidence of population mixing between Antarctic sampling areas that can be explained by physical structuring through the ACC.

Thus, the Subantarctic Front (SAF), the northern-most of the ACC fronts, flows northwards across the North Scotia Ridge and along the continental shelf off the Falkland Islands through an area noted for mesoscale eddy activity, 
looping south and eastward. The PF turns eastward soon after flowing north across the Scotia Ridge (Meredith et al. 1999a; Arhan et al. 2002), and both fronts miss South Georgia. As a consequence, marine organisms from the Falkland Islands EEZ entrained in the northward-flowing SAF would be advected back over the continental shelf. Any remaining in the SAF or PF would be transported downstream without encountering South Georgia, providing a physical segregating mechanism between South America and the Antarctic, but promoting movement along the ACC (Ashford et al. 2003; Rogers et al. 2006).

The prevailing current direction, water velocities, and spatial extent of the ACC make it unlikely that advected fish return to the areas where they were spawned; although this could occur via a circum-Antarctic pathway, mesoscale gyre circulations, or by directed migration, our results suggest that in practise, their contribution is small, at least to structuring toothfish populations. On the other hand, advection would account for the nucleus chemistry distributions we found downstream of South Georgia. The SAF and PF transport water across the South Atlantic and into the Indian Ocean where, although the average position of the SAF lies north of the Kerguelen Plateau, the PF crosses immediately north of Kerguelen Island. As a result, life stages entrained in the PF at South Georgia could be advected directly to Kerguelen. Since the SAF frequently occupies a position over the Kerguelen Plateau, life stages so entrained could be advected to Macquarie Island and on to the southern Pacific. The staggered distribution found in toothfish suggested advection of this nature along the ACC; fish with early life histories similar to north and east South Georgia occurred in smaller proportions further downstream, while a new population at Kerguelen also occurred downstream at Macquarie, and another appeared first at Macquarie and then south of South Georgia.

\section{Complex population structure and management}

If life stages of marine fish are advected by fronts, then physical processes governing frontal position may drive the rate of entrainment and abundance at downstream fishing areas. The proportions of fish mixing may be linked to frontal stability; for instance, if the proximity of the SAF to Kerguelen drives the supply of fish to Macquarie Island, their abundance at Macquarie may vary quite predictably, but lead to considerable temporal variability in mixing proportions as well as stock size.

Such linkages can undermine management if it is not coordinated between fishing areas; reducing the size of independent fishing areas is often held to be conservative (e.g., Smith and McVeagh 2000), but the size of the management area on its own is likely to have limited benefit if important sources of recruitment lie outside. Genetic heterogeneity between areas, however, as in the case of toothfish, implies that arriving fish do not breed with resident ones. Instead, advection may promote population structure consisting of members mixed with vagrants transported from spawning grounds upstream. Life history strategies to compensate for extensive losses of vagrants would explain the anomaly that some species have high fecundity rates like toothfish (e.g., Kock et al. 1985), an attribute associated with high mortal- ity, yet are long-lived and grow slowly, features more often associated with low natural mortality (e.g., Jones and Wells 1998; Wells and Jones 2002). Moreover, restriction of the breeding population to a relatively small proportion of fish able to access spawning grounds would help account for cases where strong differentiation in mtDNA is not reflected in nuclear DNA (e.g., Appleyard et al. 2002; Shaw et al. 2004).

Even though they do not contribute reproductively, vagrants are important to fishermen. They may also mitigate fishing on adults that do spawn and form an important component of local ecosystems. As a result, interruption in the movement of fish, through fishing pressure upstream or changes in advection patterns driven by global warming (e.g., Hofmann and Murphy 2004), would have serious implications for productivity and conservation. By corollary, fishing effort directed on areas where breeding members concentrate may have disproportionate effects on abundance and genetic composition, locally and in fisheries downstream.

Identifying population structure correctly is therefore critical for sustaining fisheries. Although only genetic approaches can directly address gene flow, our results show that otolith chemistry can greatly illuminate the physical and population processes underlying genetic distributions and resolve complex population structures involving mixing. Resolution in turn can provide important insights with which to refine management strategy. In the case of Patagonian toothfish, catch taken off South America may depend on fish recruiting from other fishing areas. In the Antarctic, it may depend in part on advection rates along the ACC. However, between the two regions, the chemistry strongly supports exchange restricted by physical processes associated with the PF. By enabling new ways to detect mixing and separate populations, otolith chemistry can help managers resolve complex population structure driven by advection in oceanic systems.

\section{Acknowledgements}

The authors thank observers from CCAMLR, the Falkland Islands Fisheries Department, the Chilean Instituto de Fomento Pesquero (IFOP), and the Universidad Austral de Chile (UACH), who took the samples. Dr. John Klinck, at the Center for Coastal Physical Oceanography at Old Dominion University, and Dr. Zhongxing Chen, at LITER; Pedro Rubilar, while at UACH and IFOP; and Dr. Conor Nolan, while at FIFD, gave generously of their advice and support. Dr. Christian Reiss (National Marine Fisheries Service's Antarctic Marine Living Resources Program) and Dr. Patrick Gaffney (College of Marine Studies at the University of Delaware) provided many invaluable insights and suggestions. This work was supported by the United States National Science Foundation (grant No. NSF-OPP-9614756) and through the British Antarctic Survey.

\section{References}

Appleyard, S.A., Ward, R.D., and Williams, R. 2002. Population structure of the Patagonian toothfish around Heard, McDonald and Macquarie Islands. Antarct. Sci. 14: 364-373. 
Appleyard, S.A., Williams, R., and Ward, R.D. 2004. Population genetic structure of Patagonian toothfish in the West Indian Ocean sector of the Southern Ocean. CCAMLR Sci. 11: 21-32.

Arhan, M., Naveira Garabato, A.C., Heywood, K.J., and Stevens, D.P. 2002. The Antarctic Circumpolar Current between the Falkland Islands and South Georgia. J. Phys. Oceanogr. 32: 1914-1931.

Ashford, J.R. 2001. In support of a rationally managed fishery: age and growth in Patagonian toothfish (Dissostichus eleginoides). Ph.D. dissertation, Department of Biological Sciences, Old Dominion University, Norfolk, Va.

Ashford, J.R., and Jones, C.M. 2007. Oxygen and carbon stable isotopes in otoliths record spatial isolation of Patagonian toothfish (Dissostichus eleginoides). Geochim. Cosmochim. Acta, 71: 87-94.

Ashford, J.R., Jones, C.M., Hofmann, E., Everson, I., and Duhamel, G. 2003. Is population structure of Patagonian toothfish (Dissostichus eleginoides) determined by the Antarctic Circumpolar Current? CCAMLR Sci. Papers WG-FSA-03/84. Commission of the Convention for the Conservation of Antarctic Marine Living Resources (CCAMLR), Hobart, Australia.

Ashford, J.R., Jones, C.M., Hofmann, E.E., Everson, I., Duhamel, G., Moreno, C., and Williams, R. 2005. Can otolith elemental signatures record the capture site of a fully marine fish, Dissostichus eleginoides, in the Southern Ocean? Can. J. Fish. Aquat. Sci. 62(12): 2832-2840.

Ashford, J.R., Arkhipkin, A.I., and Jones, C.M. 2006. Can the chemistry of otolith nuclei determine population structure of Patagonian toothfish (Dissostichus eleginoides)? J. Fish Biol. 69: 708-721.

Ashford, J.R., Arkhipkin, A.I., and Jones, C.M. 2007. Otolith chemistry reflects frontal systems in the Antarctic Circumpolar Current. Mar. Ecol. Prog. Ser. 351: 261-271.

Bucciarelli, E., Blain, S., and Treguer, P. 2001. Iron and manganese in the wake of the Kerguelen Islands (Southern Ocean). Mar. Chem. 73: 21-36.

Campana, S.E., Fowler, A.J., and Jones, C.M. 1994. Otolith elemental fingerprinting for stock identification of Atlantic cod (Gadus morhua) using laser ablation ICPMS. Can. J. Fish. Aquat. Sci. 51(9): 1942-1950.

Chen, Z., Canil, D., and Longerich, H.P. 2000. Automated in situ trace element analysis of silicate materials by laser ablation inductively coupled plasma mass spectrometry. Fresnius' J. Anal. Chem. 368: 73-78.

Cornuet, J.-M., Piry, S., Luikart, G., Estoup, A., and Solignac, M. 1999. New methods employing multilocus genotypes to select or exclude populations as origins of individuals. Genetics, 153: 1989-2000.

Cushing, D.H. 1981. Fisheries biology. 2nd ed. University of Wisconsin Press, Madison, Wis.

Dehairs, F., Baeyens, W., and Goeyens, L. 1992. Accumulation of suspended barite at mesopelagic depths and export production in the Southern Ocean. Science (Washington, D.C.), 258(5086): 1332-1335.

Eastman, J.T. 1993. Antarctic fish biology: evolution in a unique environment. Academic Press, San Diego, Calif.

Edmonds, J.S., Caputi, N., and Morita, M. 1991. Stock discrimination by trace-element analysis of otoliths of orange roughy (Hoplostethus atlanticus), a deep-water marine teleost. Aust. J. Mar. Freshw. Res. 42: 383-389.

Fach, B.A., Hofmann, E.E., and Murphy, E.J. 2006. Transport of Antarctic krill (Euphausia superba) across the Scotia Sea. Part II. Krill growth and survival. Deep-Sea Res. I, 53(6): 10111043. doi:10.1016/j.dsr.2006.03.007.
Harden Jones, F.R. 1968. Fish migration. Edward Amold, London, UK.

Hofmann, E.E. 1985. The large-scale structure of the Antarctic Circumpolar Current from FGGE drifters. J. Geophys. Res. 90(C4): 7087-7097.

Hofmann, E.E., and Murphy, E.J. 2004. Advection, krill, and Antarctic marine ecosystems. Antarct. Sci. 16(4): 487-499.

Hofmann, E.E., Klinck, J.M., Locarnini, R.A., Fach, B., and Murphy, E. 1998. Krill transport in the Scotia Sea and environs. Antarct. Sci. 10(4): 406-415.

Hom, P.L. 2002. Age and growth of Patagonian toothfish (Dissostichus eleginoides) and Antarctic toothfish (D. mawsoni) in waters from the New Zealand subantarctic to the Ross Sea, Antarctica. Fish. Res. 56: 275-287.

Ihssen, P.H., Booke, H.E., Casselman, J.M., McGlade, J.M., Payne, N.R., and Utter, F.M. 1981. Stock identification: materials and methods. Can. J. Fish. Aquat. Sci. 38: 1838-1855.

Jones, C.M., and Chen, Z. 2003. New techniques for sampling larval and juvenile fish otoliths for trace-element analysis with laser-ablation sector-field inductively-coupled plasma mass spectrometry (SF-ICP-MS). In The Big Fish Bang: Proceedings of the 26th Annual Larval Fish Conference, 22-26 July 2002, Os, Norway. Edited by H.I. Browman and A.B. Skiftesvik. Institute of Marine Research, Bergen, Norway. pp. 431-443.

Jones, C.M., and Wells, B. 1998. Age, growth and mortality of black drum, Pogonias cromis, in the Chesapeake Bay region. Fish. Bull. 96(3): 451-461.

Khattree, R., and Naik, D.N. 1999. Applied multivariate statistics with SAS ${ }^{\circledR}$ software. 2nd ed. SAS Institute Inc., Cary, N.C.

Khattree, R., and Naik, D.N. 2000. Multivariatedata reduction and discrimination with SAS ${ }^{\oplus}$ software. SAS Institute Inc., Cary, N.C.

Kingsford, M.J. 1993. Biotic and abiotic structure in the pelagic environment: importance to small fishes. Bull. Mar. Sci. 53(2): 393-415.

Kock, K.-H., Duhamel, G., and Hureau, J.-C. 1985. Biology and status of exploited Antarctic fish stocks: a review. BIOMASS Scientific Series 6, SCAR, Cambridge, UK.

Kroopnick, P.M. 1985. The distribution of ${ }^{13} \mathrm{C}$ of $\mathrm{CO}_{2}$ in the world oceans. Deep-Sea Res. 32(1A): 57-84.

Kruskal, J.B., and Wish, M. 1978. Multidimensional scaling. Sage Publications, Beverly Hills, Calif.

Kuehl, R.O. 1994. Statistical principles of research design and analysis. Duxbury Press, Belmont, Calif.

Loeb, V.J., Kellermann, A.K., Koubbi, P., North, A.W., and White, M.G. 1993. Antarctic larval fish assembalges: a review. Bull. Mar. Sci. 53(2): 416-449.

Meredith, M.P., Grose, K.E., McDonagh, E.L., Heywood, K.J., Frew, R.D., and Dennis, P.F. 1999a. Distribution of oxygen isotopes in the water masses of Drake Passage and the South Atlantic. J. Geophys. Res. 104(C9): 20949-20962.

Meredith, M.P., Heywood, K.J., Frew, R.D., and Dennis, P.F. 1999b. Formation and circulation of the water masses between the southern Indian Ocean and Antarctica: results from $\delta^{18} \mathrm{O}$. J. Mar. Res. 57: 449-470.

Molinelli, E.J. 1981. The Antarctic influence on Antarctic Intermediate Water. J. Mar. Res. 39: 267-293.

Moller, P.R., Nielsen, J.G., and Fosse, I. 2003. Patagonian toothfish found off Greenland. Nature (London), 421: 599.

Murphy, E.J., Watkins, J.L., Meredith, M.P., Ward, P., Trathan, P.N., and Thorpe, S.E. 2004. Southern Antarctic Circumpolar Front to the northeast of South Georgia: horizontal advection of krill and its role in the ecosystem. J. Geophys. Res.-Oceans, 109: art no. C010129. doi: 10.1029/2002JC001522. 
North, A.W. 2002. Larval and juvenile distribution and growth of Patagonian toothfish around South Georgia. Antarct. Sci. 14(1): 25-31.

Nowlin, W.D., Jr., and Clifford, M. 1982. The kinematic and thermohaline zonation of the Antarctic Circumpolar Current at Drake Passage. J. Mar. Res. 40: 481-507.

Orsi, A.H., Whitworth, T., and Nowlin, W.D. 1995. On the meridional extent and fronts of the Antarctic Circumpolar Current. Deep-Sea Res. I, 42(5): 641-673.

Oyarzun, C., Campos, P.W., and Valeria, H.R. 1988. Adaptaciones para la flotabilidad en Dissostichus eleginoides Smitt, 1898 (Pisces, Perciformes, Nototheniidae). Invest. Pesq. (Barcelona), 52 : 455-466. [In Spanish.]

Polachek, T. 1990. Year round closed areas as a management tool. Nat. Res. Model. 4: 327-354.

Pollard, R.T., Lucas, J.I., and Read, J.F. 2002. Physical controls on biogeochemical zonation in the Southern Ocean. Deep-Sea Res. II, 49: 3289-3305.

Pulliam, H.R. 1988. Sources, sinks and population dynamics. Am. Nat. 132: $652-661$.

Rogers, A.D., Morley, S., Fitzcharles, E., Jarvis, K., and Belchier, M. 2006. Genetic structure of Patagonian toothfish (Dissostichus eleginoides) populations on the Patagonian Shelf and Atlantic and western Indian Ocean sectors of the Southern Ocean. Mar. Biol. Mar. Biol. 149: 915-924.

Schiffman, S.S., Reynolds, M.L., and Young, F.W. 1981. Introduction to multidimensional scaling: theory, methods, and applications. Academic Press, New York.
Shaw, P.W., Arkhipkin, A.I., and Al-Khairulla, H. 2004. Genetic structuring of Patagonian toothfish populations in the Southwest Atlantic Ocean: the effect of the Antarctic Polar Front and deep water troughs as barriers to genetic exchange. Mol. Ecol. 13(11): 3293-3303.

Sievers, H.A., and Nowlin, W.D., Jr. 1984. The stratification and water masses at Drake Passage. J. Geophys. Res. 89: 1048910514

Sinclair, M. 1988. Marine populations: an essay on population regulation and speciation. University of Washington Press, Seattle, Wash.

Sinclair, M., and Iles, T.D. 1989. Population regulation and speciation in the oceans. J. Cons. Int. Explor. Mer, 45: 165-175.

Smith, P., and McVeagh, M. 2000. Allozyme and microsatellite DNA markers of toothfish population structure in the Southern Ocean. J. Fish Biol. 57(Suppl. A): 72-83.

Sokal, R.R., and Rohlf, F.J. 1995. Biometry. W.H. Freeman and Co., New York.

Walther, B.D., and Thorrold, S.R. 2006. Water, not food, contributes the majority of strontium and barium deposited in the otoliths of a marine fish. Mar. Ecol. Prog. Ser. 311: 125-130.

Wells, B.K., and Jones, C.M. 2002. Reproduction of black drum, Pogonias cromis, from the Chesapeake Bay region. Va. J. Sci. 53(1): 3-12.

Williams, R., Tuck, G.N., Constable, A., and Lamb, T. 2002. Movement, growth and available abundance to the fishery of Dissostichus eleginoides Smitt, 1898 at Heard Island derived from tagging experiments. CCAMLR Sci. 9: 33-48. 